\title{
Killing Clothes Lice by Holding Infested Clothes Away from Hosts for 10 Days to Control Louseborne Relapsing Fever, Bahir Dah, Ethiopia
}

\author{
Stephen C. Barker, Dayana Barker
}

Louseborne relapsing fever (LBRF) was once a cosmopolitan disease, but it now occurs only in the Horn of Africa. Recent cases in refugees to Europe made LBRF topical again. Crowded boarding houses and church dwellings in Ethiopia are analogous to the crowded air-raid shelters of World War II. Thus, we might learn from experiments the London School of Tropical Hygiene and Medicine conducted during World War II. When the vector of Borrelia recurrentis $(\mathrm{Pe}-$ diculus humanus lice) was held away from the host for 10 days, $100 \%$ of nymphal and adult lice starved to death and $100 \%$ of eggs did not hatch. We hypothesize that holding infested clothes away from hosts in plastic shopping bags will kill enough lice to control LBRF in Ethiopia. Owning 2 sets of clothes might be useful; 1 set might be held in a plastic shopping bag for 10 days to kill lice and their eggs.

$\mathrm{L}$ ouseborne relapsing fever (LBRF), which is caused by the spirochete Borrelia recurrentis, once had a cosmopolitan distribution but is now endemic only to countries in the Horn of Africa (Ethiopia, Sudan, South Sudan, and Somalia) $(1,2)$. A recent spate of cases of LBRF in refugees and migrants to Europe from the Horn of Africa underlines the point that LBRF is endemic to and prevalent in this part of Africa (3-19). LBRF is one of the top 10 reasons why persons visit healthcare clinics in Ethiopia (20). Thus, LBRF is a substantial burden on the healthcare system and, moreover, a cause of substantial illness and death, especially in day laborers, street children, and yekolotemaries (live-in church students) in cities such as Bahir Dah in the Amhara Region of the highlands of Ethiopia (altitude 1,800 m).

There have been substantial outbreaks of LBRF in Bahir Dah (21-25). Moreover, some patients with undiagnosed

Author affiliations: University of Queensland, Brisbane, Queensland, Australia (S.C. Barker); University of Queensland School of Veterinary Sciences, Gatton, Queensland, Australia (D. Barker)

DOI: https://doi.org/10.3201/eid2502.181226 febrile disease come to healthcare clinics in Bahir Dah and elsewhere in Ethiopia because of LBRF and other louseassociated diseases, such as louseborne epidemic typhus (LBET) (caused by Rickettsia prowazekii) and trench fever (caused by Bartonella quintana).

LBRF has been eradicated from all regions of the world, except the Horn of Africa, by activities that kill clothes lice (Pediculus humanus), which have also been referred to as body lice. Some of these activities have been organized public health interventions in communities, including mass delousing by steaming infested clothes with Stammers Serbian barrels, which were developed during World War I (26), and are still used today in Ethiopia (Figure 1) and elsewhere. Other activities include parents delousing clothes of their children by washing clothes in hot water $\left(\geq 60^{\circ} \mathrm{C}\right)$.

Some of these activities have been part of intentional schemes to reduce prevalence and intensity of louseborne pathogens, but most of these activities have been unintentional from the point of view of LBRF - programs to improve the cleanliness and social status of persons and their families. Lice are abhorred by most persons, and infestation with clothes lice is invariably associated, right or wrong, with low socioeconomic status. However, regardless of the motivation, activities that reduce prevalence and intensity of infestation with clothes lice have been successful in reducing prevalence and intensity of louseborne pathogens, particularly since World War II $(27,28)$.

In the context of louse-associated diseases, other authors have emphasized the benefits of washing bodies and clothes $(22,29)$; it has been reported that clothes lice prefer a dirty shirt to a clean shirt (30). Washing clothes in hot water $\left(\geq 60^{\circ} \mathrm{C}\right)$ for $>10$ min kills clothes lice and their eggs (30). However, immersion of clothes in water heated to $60^{\circ} \mathrm{C}$ by a charcoal or wood fire is costly and time-consuming for most persons in Ethiopia. 
We have studied head lice and community- and individual-level strategies to control head lice in Brisbane, Queensland, Australia, and elsewhere for many years $(>20$ years for S.C.B. and 5 years for D.B.) (31-33). When we washed the hair of infested children with soap or shampoo or with water alone, we observe deaths of only a few adult lice; nymphal instars 1, 2, and 3; and eggs of lice. It appears that head lice close their spiracles when immersed in water; lice have to be submerged in water for $\geq 19$ hours to be killed (34). Our experience with head lice led us to wash cloth that was infested with clothes lice and eggs of clothes lice only with soap or water. This cloth was naturally infested cloth in several countries and cloth infested in the laboratory with lice and eggs from the Barker isolate of the Culpepper strain of clothes lice.

Our experience with clothes lice was similar to our experience with head lice; washing infested clothes in warm or cold water for $30 \mathrm{~min}$ with or without soap or washing detergent kills few lice and their eggs, although it results in clean clothes, clean lice, and clean eggs. Attacking lice and their eggs in clothes and blankets of persons is a simple way to reduce the prevalence and intensity of louseborne pathogens, such as $B$. recurrentis (cause of LBRF) and $R$. prowazekii (cause of LBET).

Attacking lice in clothes and blankets was the first public health intervention that stopped a budding epidemic of an arthropod-associated disease: the systematic treatment of clothes of many of the 1 million inhabitants of Naples, Italy, with pyrethrum powder and DDT powder in 1943. The account of this delousing campaign in air-raid shelters and other places in Naples has been reported (35-37). This delousing intervention stopped a budding epidemic of LBET. However, systematic treatment of clothes of all of or even a large group of the inhabitants of Bahir Dah with pyrethrum powder, DDT powder, or a synthetic pyrethroid is not ideal because of its immediate and ongoing cost.

After studying data from the London School of Hygiene and Tropical Medicine (London, UK) during World War II, we conceived a strategy that might reduce the number and severity of outbreaks of LBRF in day laborers, street children, and yekolotemaries in Bahir Dah. If successful, this strategy might be adapted to other situations in the Horn of Africa and elsewhere, where louse-associated diseases still occur. The crowded boarding houses (Figure 2) that house day laborers during the heavy rainy season and crowded dwellings of yekolotemaries of Bahir Dah and other cities and towns in Ethiopia are in many ways analogous to the crowded air-raid shelters and trenches that gave respite from bombs in World War II; the boarding houses and church dwellings in Bahir Dah give respite from torrential rains during the rainy season (June-September). Thus, we might learn from the scientific and epidemiologic investigations of medical entomologists during World War
II, such as Patrick Buxton, James Busvine and Major H. S. Leeson of the London School of Tropical Hygiene and Medicine, who found that when clothes lice were held away from their host for 7 days at $10^{\circ} \mathrm{C}$, or for 10 days at any temperature, $100 \%$ of nymphal and adult lice starved and died. Moreover, when clothes lice were held at $\leq 19^{\circ} \mathrm{C}$, $100 \%$ of eggs did not hatch (died).

Our hypothesis, drawn from these data, is that holding infested clothes away from hosts in plastic shopping bags will kill enough clothes lice to control LBRF in Bahir Dah
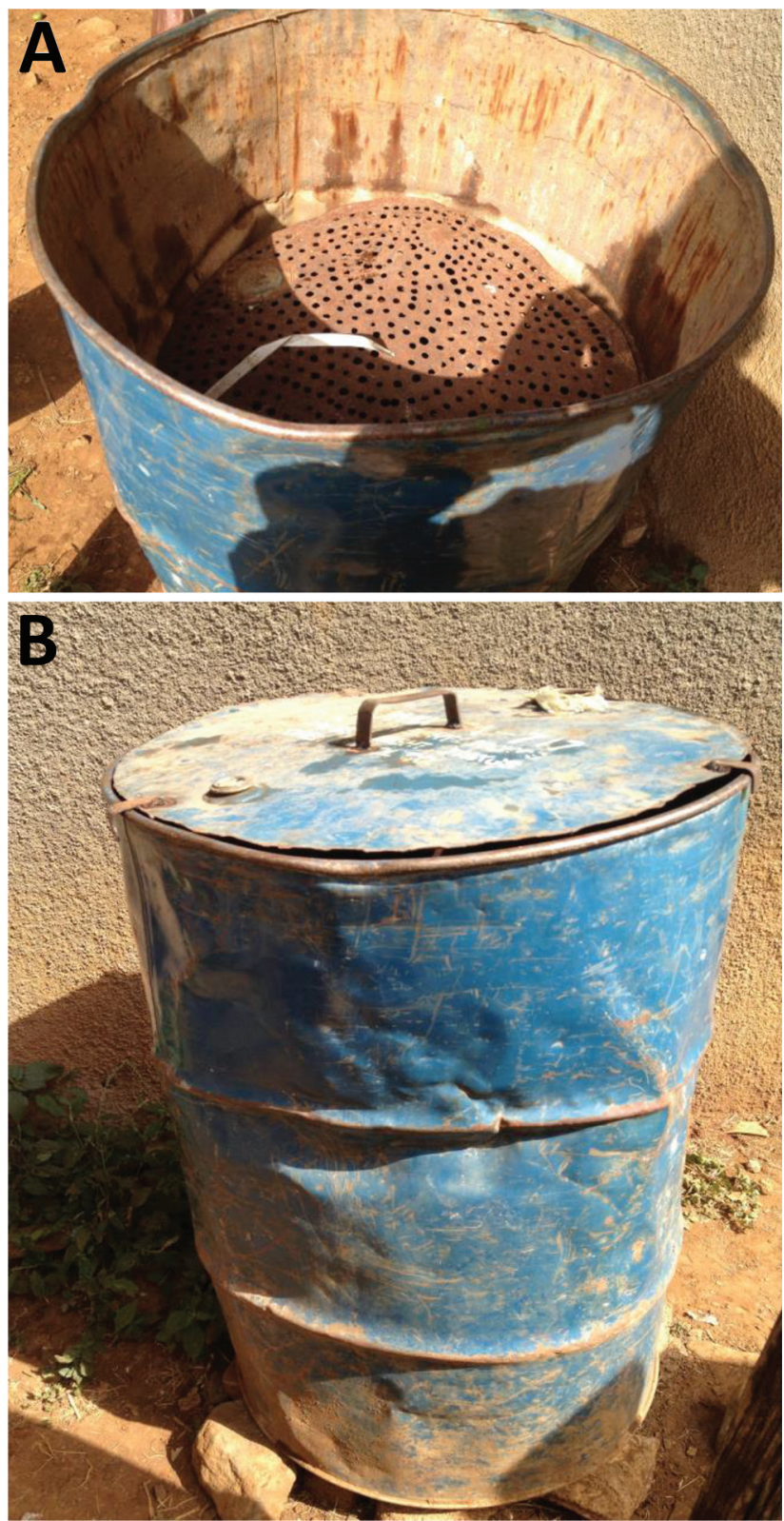

Figure 1. Wood-fired steaming barrel from a healthcare center in the highlands of Ethiopia that is used to kill clothes lice and their eggs during outbreaks of louseborne relapsing fever. A) Top view; B) front view showing lid. This $200-L$ barrel is modeled on the Stammers Serbian barrels. 


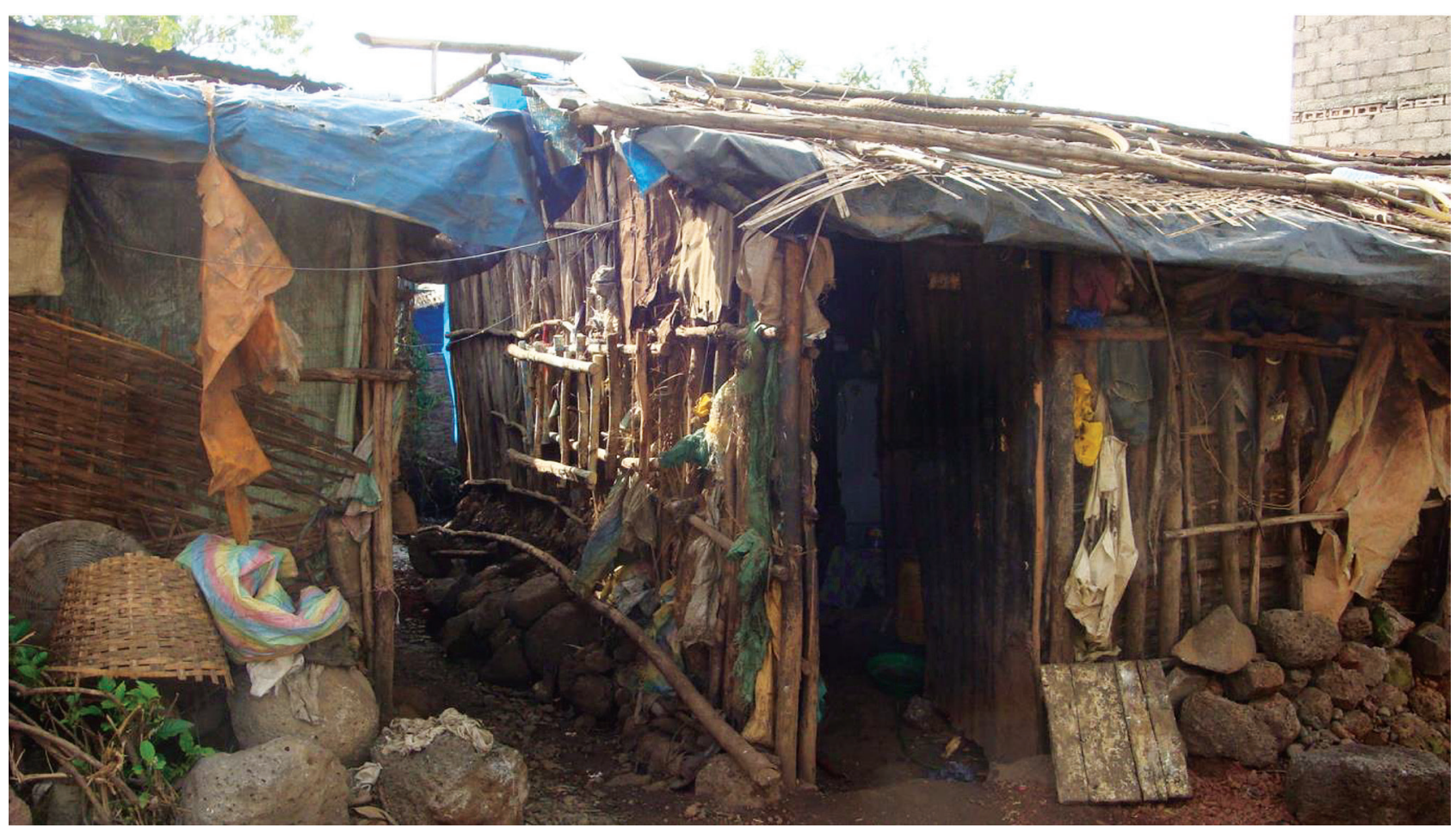

Figure 2. Typical boarding house in Bahir Dah, Ethiopia, in which many day laborers sleep at night during the heavy rainy season (June-September; Table) because it is too wet to sleep outdoors. At other times of the year when it does not rain so heavily and so often, day laborers in Bahir Dah tend to sleep outdoors and, thus, do not have to pay for lodging in boarding houses. Image courtesy of S.C. Barker.

and elsewhere in Ethiopia. Owning 2 sets of clothes would enable 1 set to be held in a plastic shopping bag for 10 days to starve to death adult and nymphal lice; even 7 days away from the host will kill most of the lice and eggs. This hypothesis might be tested in Bahir Dah and elsewhere in Ethiopia and the Horn of Africa.

It is encouraging that in at least 1 part of Ethiopia, the catchment of the Gambo General Rural Hospital in southwestern Ethiopia, the number of cases of LBRF seems to have decreased during 1997-2007 (38). The reason(s) for this decrease are unclear, although louse infestation seems to have become less intense in the patients attending the Gambo General Rural Hospital (38). We can expect a decrease in cases of LBRF in Bahir Dah and other towns and cities in Ethiopia if the prevalence and intensity of clothes lice can be substantially reduced because this has been the experience worldwide. It is not known how low the prevalence and intensity of infestation with clothes lice need to be to prevent periodic outbreaks of LBRF in day laborers, street children, and yekolotemaries in Bahir Dah (22-25). However, low-tech and simple public health strategies aimed at killing the lice and eggs that infest these 3 populations offer the prospect of reducing LBRF in these groups (22-25).

In this study, we use the name clothes lice instead of body lice for $P$. humanus lice because the name clothes

\begin{tabular}{|c|c|c|c|c|c|c|c|c|c|c|c|c|c|}
\hline \multirow[b]{2}{*}{ Variable } & \multicolumn{12}{|c|}{ Month } & \multirow[b]{2}{*}{ Year } \\
\hline & Jan & Feb & Mar & Apr & May & Jun & July & Aug & Sep & Oct & Nov & Dec & \\
\hline $\begin{array}{l}\text { Daily } \\
\text { temp., }{ }^{\circ} \mathrm{C} \\
\text { (range) }\end{array}$ & $\begin{array}{c}18.5 \\
(8-29)\end{array}$ & $\begin{array}{c}20(9- \\
31)\end{array}$ & $\begin{array}{c}21.5 \\
(11-32)\end{array}$ & $\begin{array}{c}22.5 \\
(13-32)\end{array}$ & $\begin{array}{c}22.5 \\
(13-32)\end{array}$ & $\begin{array}{c}15 \\
(13-29)\end{array}$ & $\begin{array}{c}19 \\
(13-26)\end{array}$ & $\begin{array}{c}19 \\
(13-25)\end{array}$ & $\begin{array}{c}19 \\
(12-26)\end{array}$ & $\begin{array}{c}19.5 \\
(12-27)\end{array}$ & $\begin{array}{c}19 \\
(10-28)\end{array}$ & $\begin{array}{c}18 \\
(8-28)\end{array}$ & $\begin{array}{r}20.5 \\
(11.3- \\
28.8)\end{array}$ \\
\hline $\begin{array}{l}\text { No. rainy } \\
\text { days }\end{array}$ & 1 & 1 & 2 & 3 & 10 & 18 & 28 & 28 & 20 & 10 & 3 & 1 & 125 \\
\hline $\begin{array}{l}\text { Monthly } \\
\text { rainfall, } \\
\mathrm{mm}\end{array}$ & 2 & 2 & 12 & 28 & 80 & 205 & 396 & 375 & 211 & 87 & 12 & 6 & 1,416 \\
\hline
\end{tabular}

*All values are averages. Data were obtained from the World Meteorological Organization (https://www.wmo.int/pages/index_en.html). The altitude of Bahir Dah is $1,800 \mathrm{~m}$. During the heavy rain season (June-September), it rains on most days: June, 18/30 d; July 28/31 d; August, $28 / 31 \mathrm{~d}$; and September, 20/30 d. Temp., temperature. 
lice or clothing lice (39) has at least 2 advantages over the name body lice. First, clothes lice is more accurate because, in our experience, most lice on infested persons will be found in the clothes at any time. Second, these lice go to the skin to feed. Once they have fed, they soon return to the clothes. Moreover, these lice lay most, usually all, of their eggs in clothes rather than on the body. Third, the name clothes lice draws our focus to the clothes rather than the body. Treating clothes with insecticides, steaming clothes, and changing clothes regularly has been successful in reducing the prevalence and intensity of these lice over the past 100 years since World War I. Whether clothes lice and head lice are species, subspecies, or ecotypes (sensu bacterial ecotypes) is also controversial. We have previously reviewed the history of this controversy (40), and we will not repeat it here. We will use the name $P$. humanus for clothes lice and P. capitis for head lice because in our judgment, the evidence for these lice being separate species is overwhelming (40), regardless of which concept of a species of insect is used.

We studied the data of Leeson (41) and the subsequent interpretation and contextualization of this data by Buxton (42) and Busvine (30). Our laboratory colony of P. humanus lice was started in 2000 from eggs, nymphs, and adults of the Orlando strain of $P$. humanus lice. This strain was isolated from lice at the London School of Tropical Hygiene and Medicine that were derived from the Orlando strain that had been kept for many years at the US Agriculture Bureau of Entomology and Plant Quarantine (Orlando, FL, USA). The Orlando strain of $P$. humanus lice was adapted to feeding on the blood of rabbits $(43,44)$.

\section{Killing Eggs of Clothes Lice by Holding Eggs at Suboptimal Temperatures $<32^{\circ} \mathrm{C}$}

Leeson (41) showed that 7 days at $\leq 19^{\circ} \mathrm{C}$ killed $100 \%$ of eggs of $P$. humanus clothes lice. At temperatures $>19^{\circ} \mathrm{C}$, the situation was more complicated, but the longer the eggs were held at temperatures lower than the ideal temperature for eggs $\left(32^{\circ} \mathrm{C}\right)$, the more eggs died $(41)$. We observed a complex relationship between temperatures $>19^{\circ} \mathrm{C}$ and the proportion of eggs that did not hatch (i.e., $89 \%$ did not hatch at $24^{\circ} \mathrm{C}, 66 \%$ at $26^{\circ} \mathrm{C}$, and $12 \%$ at $29^{\circ} \mathrm{C}$ ) (Figure 3). Nonetheless, keeping eggs of clothes lice at virtually any temperature $<32^{\circ} \mathrm{C}$ killed some of the eggs. The lower the temperature, the more eggs died. The longer eggs were held at suboptimal temperature, the more eggs died (41). Leeson (41) reported that favorable temperatures for $P$. humanus lice reared on the legs of humans were $30^{\circ} \mathrm{C}-32^{\circ} \mathrm{C}$ at a relative humidity of $65 \%$. Our results were similar: $29^{\circ} \mathrm{C}-32^{\circ} \mathrm{C}$ at a relative humidity of $65 \%$ for the University of Queensland isolate of the Culpepper strain of $P$. humanus lice at the University of Queensland (S.C. Barker, unpub. data). The data of Leeson (41) showed that relative humidity does not have a substantial effect on the degree of death of eggs, although low relative humidity caused additional deaths of eggs (41).

\section{Killing Nymphal and Adult Clothes Lice by Starvation}

Leeson (41) also showed that $100 \%$ of nymphal and adult clothes lice starved to death in 7 days at $10^{\circ} \mathrm{C}$ and in 10 days regardless of the temperature (Figure 4). Newly hatched nymphs are especially susceptible to starvation. If newly hatched nymphs at $32^{\circ} \mathrm{C}$ do not receive a blood meal within 48 hours of hatching, $100 \%$ will die (S.C. Barker, unpub. data, for the Barker isolate of the Culpepper strain of $P$. humanus lice). Even 24 hours without a blood meal will kill $\approx 50 \%$ of newly hatched nymphs (S.C. Barker, unpub. data, for the Barker isolate of the Culpepper strain of $P$. humanus). The lethal effect of high temperatures $\left(>60^{\circ} \mathrm{C}\right)$ on clothes lice and their eggs is well known in Ethiopia and elsewhere. Healthcare clinics in Ethiopia and elsewhere often have 200-L steel steaming drums (Stammers Serbian barrels) (Figure 1) to kill clothes lice and their eggs in infested clothes during outbreaks of LBRF. Healthcare and medical students are instructed in the steaming drum method of killing clothes lice and their eggs in clothes and on blankets, which was first reported by Hunter in $1918(45,46)$.

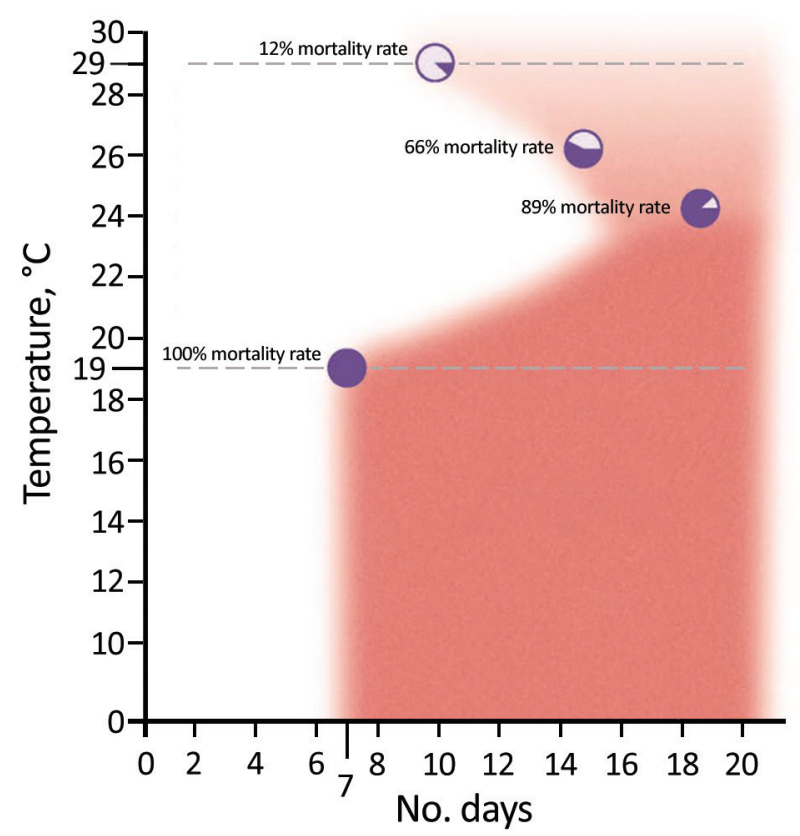

Figure 3. Mortality rates for the eggs of Pediculus humanus clothes lice, Ethiopia. Dark red shading (bottom) indicates $100 \%$ mortality rate and light red shading (top) $<100 \%$ mortality rate for eggs. At $8^{\circ} \mathrm{C}-19^{\circ} \mathrm{C}$, a total of $100 \%$ of eggs did not hatch; at $24^{\circ} \mathrm{C}$, a total of $89 \%$ of eggs did not hatch (those that hatched took 14.5 days [range $13-19$ days] to hatch); at $26^{\circ} \mathrm{C}$, a total of $66 \%$ of eggs did not hatch; and at $29^{\circ} \mathrm{C}$, a total of $12 \%$ of eggs did not hatch (88\% hatched). Dotted lines denote 12\% (top) and 100\% (bottom) mortality rate temperatures. Data were obtained from Leeson (41). 


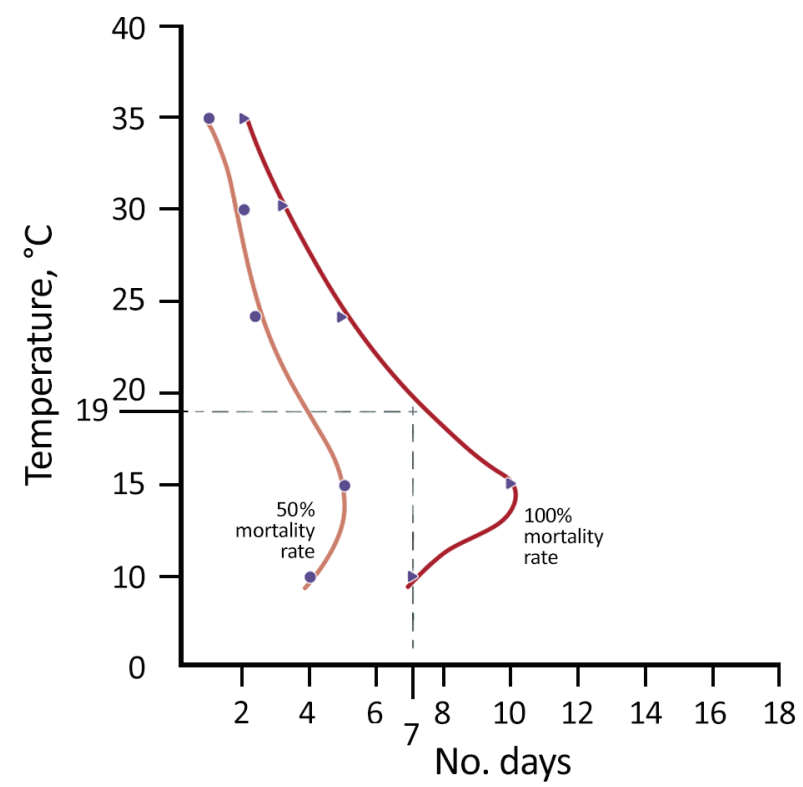

Figure 4. Number of days needed to starve to death adult and nymphal clothes lice (Pediculus humanus) at 5 temperatures $\left(10^{\circ} \mathrm{C}, 15^{\circ} \mathrm{C}, 24^{\circ} \mathrm{C}, 30^{\circ} \mathrm{C}\right.$, and $\left.35^{\circ} \mathrm{C}\right)$, Ethiopia. The mortality rate was $50 \%$ for lice after 5 days without a blood meal (i.e., away from the host) and $100 \%$ after 10 days without a blood meal, regardless of temperature. Dotted lines indicate temperatures of $0^{\circ} \mathrm{C}-19^{\circ} \mathrm{C}$ and days 0-7. Data were obtained from Buxton (42), and the figure was modified from Busvine (30).

The lethal effect of low temperatures $\left(<24^{\circ} \mathrm{C}\right)$ on clothes lice and their eggs is less well known. Clothes lice and their eggs depend on their human host. The long and intimate association between clothes lice and humans have led to clothes lice becoming completely dependent on their host for a warm environment and for food and water. In contrast to many other blood-sucking arthropods, eggs of clothes lice die in a few days at temperatures at little lower than optimum (Figure 3) (30). Moreover, clothes lice, especially newly hatched nymphs easily starve to death (Figure 4) (S.C. Barker, unpub. data). Lloyd and Byam (26), in recounting their experiences as medical servicemen in World War I, emphasized constant changing of underclothing and believed that having 2 shirts rather than 1 helped reduce infestations with clothes lice. We extend this idea to all clothes, which in tropical climates, such as in Bahir Dah, means a shirt, underpants and shorts or trousers, and a jumper or coat. In our experience, all clothes in Bahir Dah, not just underclothes, might be infested with body lice.

\section{Potential Public Health Recommendations}

If our strategy were successful, day laborers, street children, and live-in-church students in Bahir Dah might be encouraged to acquire and keep 2 sets of clothes rather than 1 set so that at any given time, 1 set of clothes might be kept in a plastic shopping bag for ideally 10 days to starve adult and nymphal lice and to kill (prevent hatching) eggs. Ten days in a plastic shopping bag at $\leq 19^{\circ} \mathrm{C}$ (e.g., on cold ceramic tile floors) should kill all eggs and lice in clothes. However, even 7 days should kill most eggs and lice (Figures 3,4).

This hypothesis needs to be tested on clothes naturally infested with clothes lice and their eggs in Bahir Dah and elsewhere. Simple experiments on the effect of holding clothes away from hosts for 7 days and for 10 days might be conducted in boarding houses and church dwellings in Bahir Dah, and among day laborers of Bahir Dah and other areas in Ethiopia. For example, placing pieces of cloth (e.g., $20 \mathrm{~cm} \times 20 \mathrm{~cm}$ ) that were cut from naturally infested clothes that have only eggs into plastic shopping bags for 7 and 10 days would determine the effect of holding clothes away from hosts on hatching and development of nymphal lice from eggs in the cloth. All nymphal and adult lice would have been gently brushed away so that only eggs are left on the pieces of cloth. In addition, we would repeat this experiment with nymphal and adult lice that were brushed from infested clothes onto uninfested cloth (no eggs present). Likely limitations and complications to our strategy include the cost of acquiring a second set of clothes, that some lice might be displaced from clothes onto sleeping mats, and the perennial problem of reinfestation through contact with other infested clothes.

We note also the prospect of treatment with oral ivermectin to kill clothes lice. Oral ivermectin may be effective against head lice $(47,48)$ and thus might also be effective against clothes lice. Therefore, oral ivermectin might be used alone or in combination with holding infested clothes away from hosts for 10 days to kill enough clothes lice to control LBRF in Ethiopia. However, a perennial problem with any kind of drug treatment is the cost, immediate and ongoing, to day laborers, street children, and yekolotemaries. In addition, resistance to ivermectin might develop in clothes lice.

\section{Acknowledgment}

We thank Richard Pollack and 2 anonymous reviewers for providing useful corrections and suggestions and Kostas Mumcuoglu for providing the Orlando strain of $P$. humanus lice.

\section{About the Authors}

Dr. Barker is a professor of parasitology at the University of Queensland, Brisbane, Queensland, Australia. His primary research interests are the biology, evolution, and control of lice and ticks.

Ms. Barker is a doctoral candidate at the School of Veterinary Science, University of Queensland, Gatton, Queensland, Australia. Her primary research interests are the taxonomy of ticks and control of lice and ticks. 


\section{References}

1. Elbir H, Raoult D, Drancourt M. Relapsing fever borreliae in Africa. Am J Trop Med Hyg. 2013;89:288-92. http://dx.doi.org/ 10.4269/ajtmh.12-0691

2. Boutellis A, Mediannikov O, Bilcha KD, Ali J, Campelo D, Barker SC, et al. Borrelia recurrentis in head lice, Ethiopia. Emerg Infect Dis. 2013;19:796-8. http://dx.doi.org/10.3201/ eid1905.121480

3. Antinori S, Mediannikov O, Corbellino M, Grande R, Parravicini C, Bestetti G, et al. Louse-borne relapsing fever (Borrelia recurrentis) in a Somali refugee arriving in Italy: a re-emerging infection in Europe? PLoS Negl Trop Dis. 2016;10:e0004522. http://dx.doi.org/10.1371/journal.pntd.0004522

4. Antinori S, Mediannikov O, Corbellino M, Raoult D. Louse-borne relapsing fever among East African refugees in Europe. Travel Med Infect Dis. 2016;14:110-4. http://dx.doi.org/10.1016/ j.tmaid.2016.01.004

5. Ciervo A, Mancini F, di Bernardo F, Giammanco A, Vitale G, Dones $\mathrm{P}$, et al. Louseborne relapsing fever in young migrants, Sicily, Italy, July-September 2015. Emerg Infect Dis. 2016;22:1523. http://dx.doi.org/10.3201/eid2201.151580

6. Colomba C, Scarlata F, Di Carlo P, Giammanco A, Fasciana T, Trizzino M, et al. Fourth case of louse-borne relapsing fever in young migrant, Sicily, Italy, December 2015: mini review article. Public Health. 2016;139:22-6. http://dx.doi.org/10.1016/ j.puhe.2016.05.019

7. Costescu Strachinaru DI, Cambier J, Kandet-Yattara H, Konopnicki D. Relapsing fever in asylum seekers from Somalia arriving in Belgium in August 2015. Acta Clin Belg. 2016;Apr 26:1-3.

8. Cutler SJ. Refugee crisis and re-emergence of forgotten infections in Europe. Clin Microbiol Infect. 2016;22:8-9. http://dx.doi.org/10.1016/j.cmi.2015.10.018

9. Cutuli SL, De Pascale G, Spanu T, Dell'Anna AM, Bocci MG, Pallavicini F, et al. Lice, rodents, and many hopes: a rare disease in a young refugee. Crit Care. 2017;21:81. http://dx.doi.org/10.1186/ s13054-017-1666-5

10. Darcis G, Hayette MP, Bontems S, Sauvage AS, Meuris C, Van Esbroeck M, et al. Louse-borne relapsing fever in a refugee from Somalia arriving in Belgium. J Travel Med. 2016;23:taw009. https://oi.org/10.1093/jtm/taw009

11. Grecchi C, Zanotti P, Pontarelli A, Chiari E, Tomasoni LR, Gulletta M, et al. Louse-borne relapsing fever in a refugee from Mali. Infection. 2017;45:373-6. http://dx.doi.org/10.1007/ s15010-017-0987-2

12. Hytönen J, Khawaja T, Grönroos JO, Jalava A, Meri S, Oksi J. Louse-borne relapsing fever in Finland in two asylum seekers from Somalia. APMIS. 2017;125:59-62. http://dx.doi.org/10.1111/ apm. 12635

13. Jochum J, Tannich E, Tappe D, Schmiedel S. A Somali refugee with fever and abnormal blood smear [in German]. Internist (Berl). 2017;58:287-92. http://dx.doi.org/10.1007/s00108-016-0154-3

14. Keller C, Zumblick M, Streubel K, Eickmann M, Müller D, Kerwat M, et al. Hemorrhagic diathesis in Borrelia recurrentis infection imported to Germany. Emerg Infect Dis. 2016;22:917-9. http://dx.doi.org/10.3201/eid2205.151557

15. Lucchini A, Lipani F, Costa C, Scarvaglieri M, Balbiano R, Carosella $\mathrm{S}$, et al. Louseborne relapsing fever among East African refugees, Italy, 2015. Emerg Infect Dis. 2016;22:298-301. http://dx.doi.org/10.3201/eid2202.151768

16. Osthoff M, Schibli A, Fadini D, Lardelli P, Goldenberger D. Louse-borne relapsing fever: report of four cases in Switzerland, June-December 2015. BMC Infect Dis. 2016;16:210. http://dx.doi.org/10.1186/s12879-016-1541-z

17. Seilmaier M, Guggemos W, Wieser A, Fingerle V, Balzer L, Fenzl T, et al. Louse-borne-relapsing-fever in refugees from the
Horn of Africa; a case series of 25 patients [in German]. Dtsch Med Wochenschr. 2016;141:e133-42.

18. Seilmaier M, Guggemos W, Alberer M, Wendtner CM, Spinner CD. Infections among refugees [in German]. Rettungsmedizin. 2017;20:216-27. http://dx.doi.org/10.1007/ s10049-016-0252-8

19. Zammarchi L, Antonelli A, Bartolini L, Pecile P, Trotta M, Rogasi PG, et al. Louse-borne relapsing fever with meningeal involvement in an immigrant from Somalia to Italy, October 2015. Vector Borne Zoonotic Dis. 2016;16:352-5. http://dx.doi.org/10.1089/vbz.2015.1928

20. Eguale T, Abate G, Balcha F. Relapsing fever in Hossana, Ethiopia: a clinical and epidemiological study. Ethiopian Journal of Health Science. 2002;12:103-8.

21. Sundnes KO, Haimanot AT. Epidemic of louse-borne relapsing fever in Ethiopia. Lancet. 1993;342:1213-5. http://dx.doi.org/ 10.1016/0140-6736(93)92190-5

22. Kassa AW, Mosie TB. Relapsing fever outbreak investigation in Bahir-Dar, Amhara Region, Ethiopia. Science Journal of Public Health. 2014;2:284-7. http://dx.doi.org/10.11648/ j.sjph.20140204.16

23. Yimer M, Mulu W, Ayalew W, Abera B. Louse-borne relapsing fever profile at Felegehiwot referral hospital, Bahir Dar city, Ethiopia: a retrospective study. BMC Res Notes. 2014b;7:250. http://dx.doi.org/10.1186/1756-0500-7-250

24. Yimer M, Abera B, Mulu W, Bezabib B. Knowledge, attitude and practices of high risk populations on louse- borne relapsing fever in Bahir Dar city, north-west Ethiopia. Science Journal of Public Health. 2014;2:15-22. http://dx.doi.org/10.11648/j.sjph.20140201.13

25. Yimer M, Abera B, Mulu W, Bezabih B, Mohammed J. Prevalence and risk factors of louse-borne relapsing fever in high risk populations in Bahir Dar city northwest, Ethiopia. BMC Res Notes. 2014a;7:615. http://dx.doi.org/10.1186/1756-0500-7-615

26. Lloyd L, Byam W. Lice and their menace to man: Edinburgh (UK): Frowde; 1919.

27. Cutler SJ, Abdissa A, Trape JF. New concepts for the old challenge of African relapsing fever borreliosis. Clin Microbiol Infect. 2009; 15:400-6. http://dx.doi.org/10.1111/j.1469-0691. 2009.02819.x

28. Cutler SJ, Bonilla EM, Singh RJ. Population structure of East African relapsing fever Borrelia spp. Emerg Infect Dis. 2010;16:1076-80. http://dx.doi.org/10.3201/eid1607.091085

29. Gratz NG. Epidemiology of louse infestations. New York: Marcel Dekker; 1985. p. 187-98.

30. Busvine JR. Bionomics of lice. Scientific publication no. 263. Washington (DC): Pan American Health Organization; 1973. p. 149-68.

31. Barker SC, Altman PM. A randomised, assessor blind, parallel group comparative efficacy trial of three products for the treatment of head lice in children-melaleuca oil and lavender oil, pyrethrins and piperonyl butoxide, and a "suffocation" product. BMC Dermatol. 2010;10:6. http://dx.doi.org/10.1186/ 1471-5945-10-6

32. Barker SC, Altman PM. An ex vivo, assessor blind, randomised, parallel group, comparative efficacy trial of the ovicidal activity of three pediculicides after a single application-melaleuca oil and lavender oil, eucalyptus oil and lemon tea tree oil, and a "suffocation" pediculicide. BMC Dermatol. 2011;11:14. http://dx.doi.org/10.1186/1471-5945-11-14

33. Barker SC, Burgess I, Meinking TL, Mumcuoglu KY. International guidelines for clinical trials with pediculicides. Int J Dermatol. 2012;51:853-8. http://dx.doi.org/10.1111/ j.1365-4632.2011.05446.x

34. Mumcuoglu KY, Friger M, Cohen R. Use of temperature and water immersion to control the human body louse (Anoplura: 
Pediculidae). J Med Entomol. 2006;43:723-5. http://dx.doi.org/ 10.1093/jmedent/43.4.723

35. Wheeler CM. Control of typhus in Italy 1943--1944 by use of DDT. Am J Public Health Nations Health. 1946;36:119-29. http://dx.doi.org/10.2105/AJPH.36.2.119

36. Soper FL, Davis WA, Markham F, Eiehl LA, Buck P. Louse powder studies in North Africa. Arch de I'Institut Pasteur d'Algerie. 1943;23:183-223.

37. Service AP. DDT, weapon against disease. In: Service AP, editor. War Department film bulletin. United States: Bethesda (MD): NIH US National Library of Medicine digital Collections; 1945.

38. Ramos JM, Malmierca E, Reyes F, Tesfamariam A. Results of a 10-year survey of louse-borne relapsing fever in southern Ethiopia: a decline in endemicity. Ann Trop Med Parasitol. 2008;102:467-9. http://dx.doi.org/10.1179/136485908X300887

39. Cutler SJ. Relapsing fever borreliae: a global review. Clin Lab Med. 2015;35:847-65. http://dx.doi.org/10.1016/j.cll.2015.07.001

40. Xiong H, Campelo D, Boutellis A, Raoult D, Alem M, Ali J, et al. SNPs in entire mitochondrial genome sequences (approximately $15.4 \mathrm{~kb}$ ) and cox 1 sequences (approximately $486 \mathrm{bp}$ ) resolve body and head lice from doubly infected people from Ethiopia, China, Nepal, and Iran but not France. J Med Entomol. 2014a;51: 1199-207. http://dx.doi.org/10.1603/ME14001

41. Leeson HS. The effect of temperature upon the hatching of the eggs of Pediculus humanus corporis de Geer (Anoplura). Parasitology. 1941;33:243-9. http://dx.doi.org/10.1017/S0031182000024434
42. Buxton PA. The louse: an account of the lice which infest man, their medical importance and control. London: Edward Arnold; 1947.

43. Culpepper GH. Factors influencing the rearing and maintenance of a laboratory colony of the body louse. J Econ Entomol. 1946;39:472-4. http://dx.doi.org/10.1093/jee/39.4.472

44. Culpepper GH. The rearing and maintenance of a laboratory colony of the body louse. Am J Trop Med. 1944;s1-24:327-9. http://dx.doi.org/10.4269/ajtmh.1944.s1-24.327

45. Hunter W. A lecture on the prevention and arrest of lice-borne diseases by new methods of disinfection. Lancet. 1918;192:347-51. http://dx.doi.org/10.1016/S0140-6736(00)95758-1

46. Hunter W. New methods of disinfection for the prevention and arrest of lice-borne diseases (typhus, relapsing, and trench fevers). BMJ. 1918;2:198-201

47. Chosidow O, Giraudeau B, Cottrell J, Izri A, Hofmann R, Mann SG, et al. Oral ivermectin versus malathion lotion for difficult-to-treat head lice. N Engl J Med. 2010;362:896-905. http://dx.doi.org/10.1056/NEJMoa0905471

48. Pariser DM, Meinking TL, Bell M, Ryan WG. Topical 0.5\% ivermectin lotion for treatment of head lice. N Engl J Med. 2012;367:1687-93. http://dx.doi.org/10.1056/NEJMoa1200107

Address for correspondence: Stephen C. Barker, Parasitology Section, School Chemistry and Molecular Biosciences, University of Queensland, Brisbane 4072, Queensland, Australia; email: s.barker@uq.edu.au

\section{EID Podcast: Louseborne Relapsing Fever in Europe}

Louseborne relapsing fever was once widely distributed in all geographic areas, including Europe and North America, occurring in association with poverty and overcrowding. The causative agent is the spirochete bacterium Borrelia recurrentis. In nature, the only relevant vector is the body louse, which feeds only on humans; no other reservoir for this infection is known. 